\title{
Mining engineering system as an energy asset in industry 4.0
}

\author{
Dmitriy Radchenko ${ }^{1 *}$, Alina Bondarenko ${ }^{1}$ \\ ${ }^{1}$ IPKON RAS, 111020 Moscow, Russia
}

\begin{abstract}
Mines now absorbing Industry 4.0 technologies face the challenges of production energy efficiency enhancement and energy safety improvement. Following the environmental standards involves the requirement of turning from diesel to electric drive of mining machinery and equipment. This significantly improves miners' working environment in ore mines. At the same time, the share of energy consumption increases in the situation of low energy security of mines, particularly at peak loads. The article discusses the conditions, and proposes a scenario of mine energy supply system reliability enhancement. For this purpose, a mining engineering system is viewed as an energy asset, with identification of its expanding capabilities.
\end{abstract}

\section{Introduction}

Global trends of all without exception large production corporations joining Industry 4.0 give a conclusive interpretation of the prospects of mining industry development - transition to intelligent control systems with the alteration of the role of the human factor in design and development, as well as operation of mining engineering systems and their health monitoring.

Industry 4.0 is not only and not so much new technologies; rather, it is a new approach to production and consumption. It is based on the principles of sustainable development, implementation of "green" technologies, collection of big data, their processing and use for coordinated actions and operation timing performed without human intervention. The base trend of Industry 4.0 development is the attribution of such functions as optimization and setting of autonomous operation to machines and mechanisms.

As a result, the country's mining complex, which is already an energy-intensive sector $(6 \%$ of the total power generation of Russia [1]; as an average, 1 tonne of coal output requires $50.5 \mathrm{kWh}$; that of gold $-250 \mathrm{kWh}$; and that of bauxite $-13 \mathrm{kWh}$ ), on a mid-term horizon it is expected to increase energy consumption for process needs. It is explained by the fact that Industry 4.0 base technologies, such as robotization, digitization of deposit sites and production processes, positioning of machinery and mine personnel, collection, storage and processing of big data, cybersecurity provision and some other are rather energy-intensive.

The main obstacle preventing the application of Industry 4.0 principles and technologies is the current high share of diesel-driven machinery and mechanisms both in terms of environmental safety (restrictions and consequences of the personnel attendance in toxic zones and ICE-driven machinery gas emissions), and technology features (mines have to spend up to $40 \%$ of the total energy for ventilation to remove exhaust gases of mine transport machinery). Even in technologically developed mining countries the share of energy generated as a result of diesel fuel combustion and consumed in technological processes of mining reaches $45 \%$ [2]. In Russia, it is impartially higher and accounts for $75 \%$ as an average. On the one hand, this can be explained by the fact that a significant share of mines operates in the areas with poor energy infrastructure, and by the widespread use of heavy load-haul-dump machinery and dump trucks with diesel engines in underground mines, on the other hand.

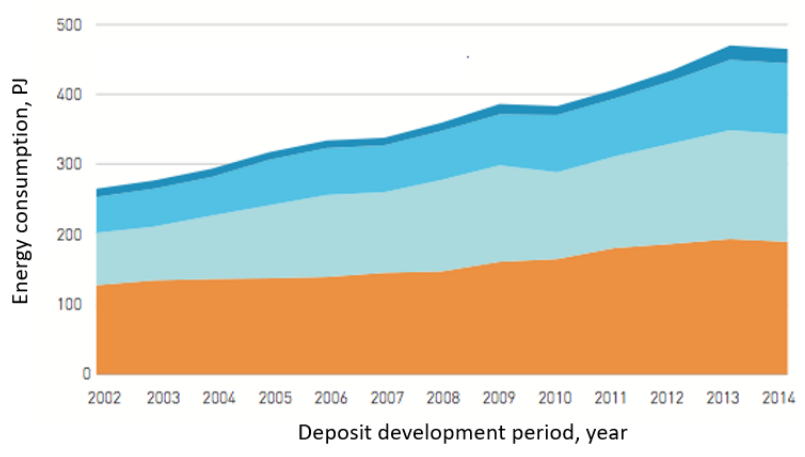

Fig. 1. Energy consumption patterns of mines in developed mining countries [2]

In this context, a cross-cutting priority of mining and energy engineering is the identification of expanding capabilities of energy in mining engineering systems for the enhancement of energy efficiency, industrial, energy and environmental safety of production with the minimization of the share of diesel fuel-fired power plants and internal combustion engines in the total pattern of energy consumption of mines. 


\section{Research methods}

Analysis of mine behavioural and investment models aimed at the enhancement of energy security of processes and perfection of energy safety is the main research method.

Research has been performed into the world practice of mines' approaches to the application of renewable energy.

Expandable capabilities of a mining engineering system have been identified, namely, energy sources, which can be specified as technology-related, i.e., caused by and existing as a result of human intervention underground [1]. Analysis of the following expandable capabilities has been made:

- renewable energy sources (solar and wind energy, geothermal energy);

- technology-related sources (energy of in-mine air flow, energy of in-mine hydraulic flows).

Design and development of mining engineering systems have been performed and 4 most probable generic design patterns have been identified, in which the application of technology-related sources of energy of a mining engineering system is feasible.

\section{Key research findings}

Transition to Industry 4.0 in the mining sector must be based on the phase-out of the application of load-haul and transport machinery with diesel engines.

Transition to load-haul-dump machinery and underground dump trucks with electric drives will minimize operation costs and provide environmental advantages in transition to mineral mining at deep horizons with high temperatures, as well as in conditions, where ventilation costs are of critical importance. Main concepts reflecting the advantages and shortcomings of mine underground transport machinery application options are provided in Table 1. For the first time in mining industry RDH's heavy 3 TEB Muckmaster LHD was demonstrated in May 2016. The payload capacity of this model is $3 \mathrm{t}$, its bucket capacity is $1.15 \mathrm{~m} 3$. The machine is powered by an Artisan LiFePO4 battery. Currently, the only electricallypowered LHD manufactured in Russia based on powerstorage unit goes through testing (Rosatom).

Table 1. Alternative options of mine transport machinery

\begin{tabular}{|l|l|l|l|}
\hline No & Notations & \multicolumn{2}{|c|}{ Key features } \\
\cline { 3 - 4 } & Diesel & $\begin{array}{l}\text { Advantages } \\
\text { low cost, } \\
\text { large-scale } \\
\text { production, } \\
\text { tried and tested } \\
\text { operation practice. }\end{array}$ & $\begin{array}{l}\text { High } \\
\text { environmental } \\
\text { hazard, inability to } \\
\text { operate in confined } \\
\text { space because of } \\
\text { temperature and } \\
\text { oxygen content } \\
\text { requirements, } \\
\text { inability to operate } \\
\text { as robotized } \\
\text { equipment. }\end{array}$ \\
\hline 2 & Electric cable & $\begin{array}{l}\text { Low heat } \\
\text { emission; } \\
\text { advantageous } \\
\text { requirements to }\end{array}$ & $\begin{array}{l}\text { Limited mobility, } \\
\text { and thus inability } \\
\text { to adapt to } \\
\text { robotized working }\end{array}$ \\
\hline
\end{tabular}

\begin{tabular}{|c|c|c|c|}
\hline & & $\begin{array}{l}\text { ventilation of } \\
\text { underground } \\
\text { workings and } \\
\text { volume of air } \\
\text { supply; } \\
\text { Low operation } \\
\text { costs. }\end{array}$ & $\begin{array}{l}\text { conditions; } \\
\text { problematic } \\
\text { turnout in } \\
\text { underground } \\
\text { workings; high } \\
\text { wear of cables; } \\
\text { high capital costs; } \\
\text { risk of short circuit } \\
\text { with disablement } \\
\text { of a power supply } \\
\text { system section, } \\
\text { high safety } \\
\text { requirements. }\end{array}$ \\
\hline 3 & Storage battery & $\begin{array}{l}\text { High mobility, } \\
\text { robotization } \\
\text { opportunity, 4-fold } \\
\text { cutting of energy } \\
\text { costs as compared } \\
\text { to diesel-driven } \\
\text { analogs, free from } \\
\text { hydrostatic oil and } \\
\text { filters; hydraulic } \\
\text { oil change at 2- } \\
\text { year intervals; } \\
\text { favorable } \\
\text { requirements to } \\
\text { ventilation of } \\
\text { underground } \\
\text { workings; low } \\
\text { heat emission. }\end{array}$ & $\begin{array}{l}\text { High cost, need of } \\
\text { organizational and } \\
\text { engineering } \\
\text { solutions for } \\
\text { battery charging in } \\
\text { conditions of } \\
\text { underground } \\
\text { mines, higher } \\
\text { energy } \\
\text { consumption of } \\
\text { mines; compulsory } \\
\text { retraining of mine } \\
\text { workers with the } \\
\text { issue of work } \\
\text { permits for them. }\end{array}$ \\
\hline
\end{tabular}

The analysis of data from Table 1 shows that in addition to high costs the main obstacle preventing the application of mining machinery with electric drives based on power storage units (storage batteries) are high loads on a mine power supply system.

Studying of the approaches to mine power supply and energy security problem solution has shown that use is made of numerous business models, which may help mining companies enhance their energy efficiency, and get profit due to application of renewable energy sources [4]. It has been found that some large mining companies, such as MSPL Limited or Essel Mining \& Industries Limited, expanded the area of their activity and launched wind parks. Their activity in the area of renewable energy sources is not directly connected with their mining business. They generate electricity both for their own consumption, and for supply to outside consumers. There exist many other business models, in which electricity generated by windpower plants and solar-cell panels is consumed directly by mines. As many mining companies do not view electricity generation as a component of their scope of main competences, there appear broad opportunities for outside investors and power plant leasing models. Particularly an area of renewable energy development in remote regions, where diesel-generator substations are the only energy source, is being shaped up.

In Russia, where conditions for the implementation of technologies of energy regeneration due to natural sources are rather limited because of unfavourable weather and climate, as well as the current level of technological development, it is necessary to seek alternative scenarios. It is proved by well-known research monographs on energy [5-6].

For the enhancement of operation energy efficiency of mining engineering systems equipped with robotized 
machinery the IPKON Department of the Theory of Mineral Deposit Development Planning has proposed an approach to consumed electric energy compensation due to the application of in-mine electricity regeneration plants in mineral deposit mining. [3, 7]. Energy conversion of mine flows, which volume in underground mines is considerable, is the most promising area (Table 2, [8]). Analysis of Table 2 shows that even at not very deep mines with the mining depth of not more than 400 $\mathrm{m}$, the water inflow may reach $500 \mathrm{~m} 3 / \mathrm{h}$, while at deeper mines it exceeds $1000 \mathrm{~m} 3 / \mathrm{h}$. It is important to note that the total volume of mine water goes by gravity to lower horizons (Fig. 2, a), from where it is pumped to the surface. At mines of $4,000 \mathrm{~m}$ depth the total length of underground workings may reach $900 \mathrm{~km}$, i.e., underground mines, as a rule, have an extensive network of vertical, inclined and horizontal workings, boreholes for water transfer from one horizon to another (vertical boreholes for mine water) providing the migration of mine water gravity flows.

Table 2. Classification of deposits by hydrogeological conditions of mining

\begin{tabular}{|c|c|c|}
\hline Group & $\begin{array}{c}\text { Mining depth, } \\
\mathrm{m}\end{array}$ & $\begin{array}{c}\text { Expected inflow of } \\
\text { mine water, } \mathrm{m}^{3} / \mathrm{h}\end{array}$ \\
\hline I & $200-400$ & below 500 \\
\hline II & $500-600$ & $500-1000$ \\
\hline III & Свыше 600 & over 1000 \\
\hline IV & Свыше 1000 & the same \\
\hline
\end{tabular}

Moreover, according to the requirements to underground mine planning, at each underground mine its horizontal workings are driven with a 2-3-degree pitch towards the mine shaft. As a result, the total volume of water is accumulated in the main drain sump and then pumped to the surface and disposed to the environment with or without preliminary treatment.

It is evident that energy efficiency of mining engineering systems, in which so much energy is spent for water drainage (and ventilation, as can be seen above), is rather low.

For the enhancement of energy efficiency of mining engineering systems it is proposed to alter the requirements to planning and design of underground working drivage. The new philosophy of mine water disposal is shown in Fig. 2-b. According to the proposed philosophy, water is accumulated at each horizon due to the workings incline turning from the shaft to the periphery. As a result, at each horizon there will be an opportunity of water accumulation for its controlled transfer to the lower horizon, and so on from overlying to underlying horizons. Energy of mine flows formed this way may be and must be converted to electricity. With the current depth of modern underground mines and rather impressive opportunities of water transfer from one horizon to another (any structure can be built) the proposed mining and engineering system planning and design philosophy seems rather promising.

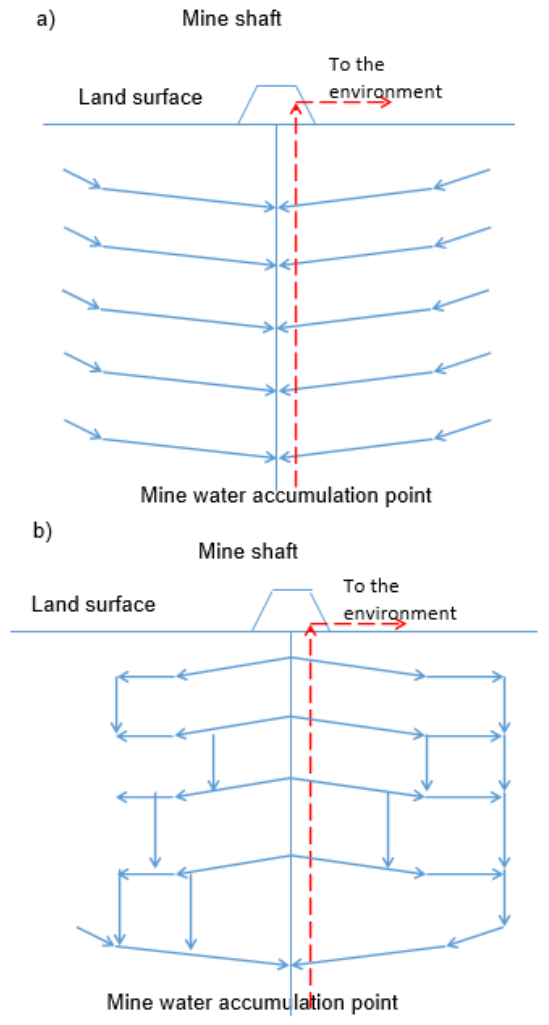

Fig. 2. Philosophy of mine water drainage design applicable globally (a) and proposed for regeneration of energy of mine flows (b). Direction of water outflow and transfer from one horizon to another is shown by arrows.

For grounding of electricity regeneration plant parameters (small HPP, underground hydroelectric pumped storage power plants) it is important to rely on the estimates of geological, hydrogeological and mining conditions of ore deposit development determining the volume of water inflow to a mine due to continuous inflow of ground waters and peak water inflows resulting from precipitations and snow melting. Such estimates must be made as early as at the stage of mine planning on the basis of comprehensive research of geological, hydrogeological and mining conditions of deposit development. In this case, geological conditions cover: strata pressure, chemical composition of surface and ground waters, quantity and thickness of aquifers, ground water flow connection with surface water bodies and watercourse, nature of ground water migration and filtration properties of rock in the large, as well as concentration of suspended particles and solid impurities [9].

Furthermore, the value of energy flows will depend on the volumes of hydraulic mixture $\left(\mathrm{Q}_{\mathrm{gm}}, \mathrm{m}^{3} / \mathrm{h}\right)$, its density, difference in elevations and equipment used for energy conversion (Fig. 3). The results of preliminary estimation show that in heavily-watered mines during the transfer of water at a rate of $5 \mathrm{~m}^{3} / \mathrm{s}$ from a horizon lying $70 \mathrm{~m}$ higher than underlying horizon may generate up to $70 \mathrm{MW}$ of electrical power. It is evident that this amount of energy is sufficient for energy supply of a mine, especially in view of the fact that for the achievement of the objective of mine transfer from mine 
machinery with diesel engines to those equipped with environmentally safe electric drives.

Yet, mine water flows of horizons are not of permanent volume, i.e. there may be peak inflows, but in some periods water does not actually flows to a mine or some of the horizons. Therefore, design, manufacture and use of energy storage installations, including storage battery systems for operation of transport machinery in mines are very important tasks.

It is a forward-looking idea to install these systems at each horizon, where at the same time:

- work is under way on mineral mining with the use of robotized LHD units with storage batteries. Judging by the available data, such storage batteries must be charged after 4-hour operation, with the charging time of 1.5-2 hours;

- water flow transfer is provided;

- energy regeneration complex including a generatorinverter (transformer) - energy-storage system is in operation.

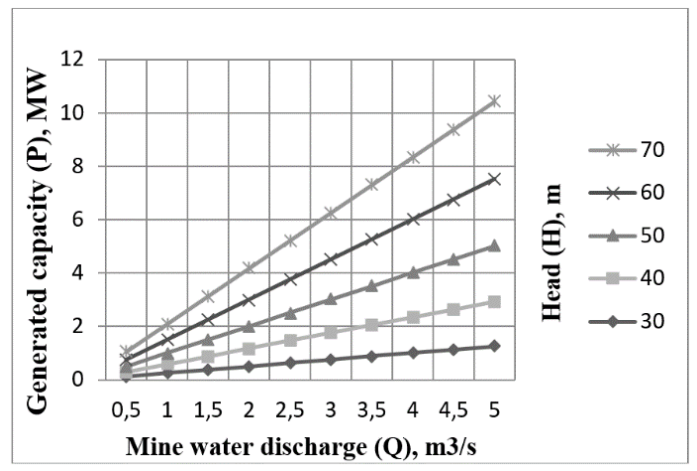

Fig.3. Dependence of regenerated capacity on the volume of mine water transferred from one mine horizon to another and head (distance between horizons).

The principle of charging plant location for the replacement of robotized equipment storage batteries at an underground mine horizon is shown in Fig. 4. The analysis of Fig. 3 shows that the scheme includes 2 energy generation and storage systems; moreover, the system on the overlying horizon converts energy of a mine flow transferred from horizons 1 and $2\left(Q_{1}+Q_{2}\right)$ to the third underlying horizon. The underlying system of energy generation and storage converts the energy of mine water flows from three horizons $\mathrm{Q}_{1}+\mathrm{Q}_{2}+\mathrm{Q}_{3}$ and it has the highest capacity.

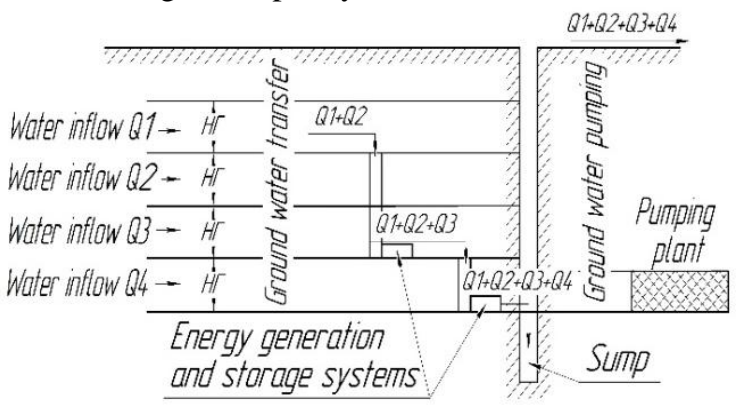

Fig. 4. Principle of installation of a charging plant for mine battery-powered transportation machinery in an underground mine.
It is envisaged that robotized equipment with batterypowered electric drives, when necessary, goes to energy storage systems for battery replacement and then back to ore mining operation.

The analysis of the schematic diagrams shown in Fig. 2 and Fig. 4 proves the fact that the mine consumes electric energy for drainage of the total water inflow, ventilation, etc., and it also regenerates it. This suggests the conclusion that the energy balance of the mining engineering system as an energy asset of Industry 4.0 can be defined as:

$$
E_{m e s}=E_{r}-E_{c}
$$

where $E_{m e s}$ is the total energy of the mining engineering system, $\mathrm{MW} / \mathrm{h} ; \mathrm{E}_{\mathrm{r}}$ is regenerated energy, $\mathrm{MW} / \mathrm{h} ; \mathrm{E}_{\mathrm{c}}$ is consumed energy, $\mathrm{MW} / \mathrm{h}$.

It is evident that if the total water inflow is pumped, such energy balance is negative, i.e., $E_{r}<E_{c}$. Such standard mining engineering systems are shown in Fig. 5-a and Fig. 5-b. However, it has been found that two fundamentally different mining situations are possible, when the energy balance of the mining engineering system described by formula 1 will be positive. Such standard design options of mining engineering systems are shown in Fig. 5.

According to the data of Fig. 5-c, deposit development takes place in the upland area. The total water inflow is transferred stepwise from upper to lower horizons, while energy generation and storage systems are installed on the third, second and first horizons. After water transfer to the lower horizon the total water inflow goes by gravity to the environment, i.e., the mine spends nothing for forced water drainage.

According to the diagram shown in Fig. 5-d the ore body is mined in the wall of a depleted open pit. In this case, after electric energy generation and accumulation the total water inflow goes by gravity to the depleted open pit. Thus, no water pumping from the underground mine takes place. It suggest a conclusion that the energy balance of the mining engineering system looks as follows: $E_{r}>E_{c}$, i.e., in these conditions (Fig. 5-c and Fig. 5-d) the mine is able to generate more energy than it consumes.

With regard to the balance equation 1 it is important to note that this is the case of implementation of Industry 4.0 environmentally safe technologies in the mine, i.e. ore mining technologies without application of mine LHD and transport machinery with diesel engines. In other words, mining engineering system with the positive balance $\left(E_{r}>E_{c}\right.$ condition) means the situation, when there are no $40 \%$ ventilation costs due to the application of battery-powered equipment, and no water drainage costs. 
(a)

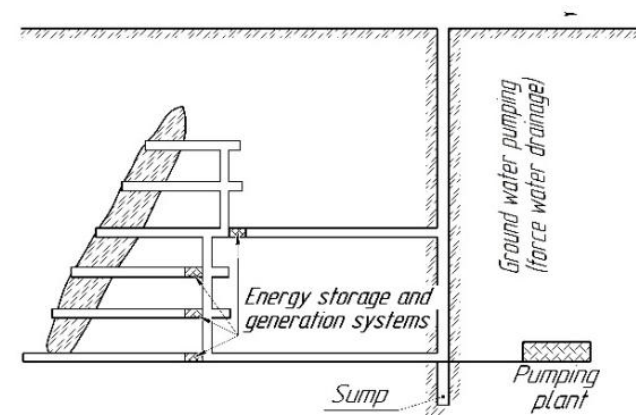

(b)

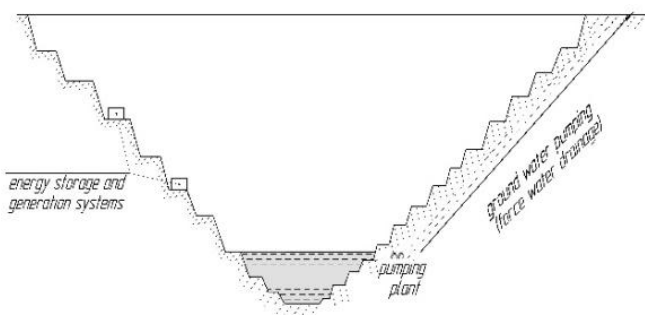

(c)

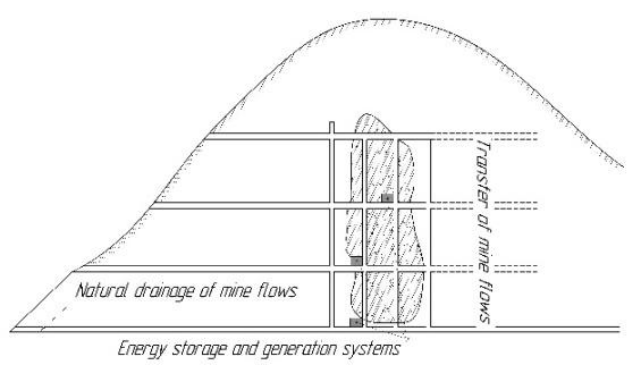

(d)

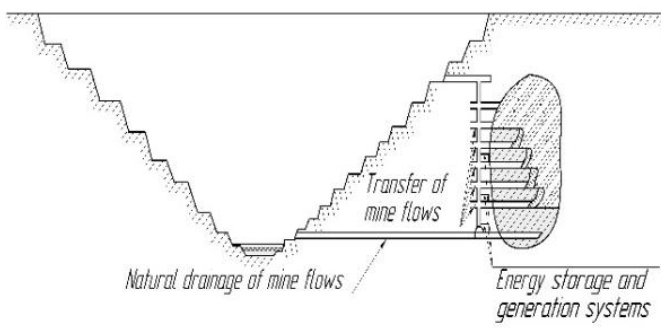

Fig. 5. Typical mining engineering systems and opportunities for energy production with forced pumping out of mine waters $(\mathrm{a}, \mathrm{b})$ and natural water disposal $(\mathrm{c}, \mathrm{d})$

\section{Conclusions}

A mining engineering system, which was designed earlier based on conditions and restrictions concerning work environment of people, in the future, with the development of remote and robotized geotechnologies, autonomous equipment for rock mass monitoring, and combination of these technologies, will be based on grounded parameters of mine structures and geotechnologies aimed only at the provision of conditions for operation of robotized and autonomously controlled machinery in zones of mining operations.
Elimination of the necessity of health and safety requirements concerning people attendance in these zones, as well as restrictions in terms of industrial safety determines new approaches to the formation of mining engineering systems and grounding of the living environment parameters in a mining engineering system and in the area of its influence.

The situation with launching of Industry 4.0 technologies based on the application of robotized environmentally safe equipment with electric drives, implementation of measures on the enhancement of energy efficiency on the basis of mining technologyrelated energy sources is either poorly developed or even has not got any start in the international practice. Therefore, setting a target of mine re-equipment on the basis of energy cost compensation due to conversion of mine flow energy within a mining engineering system seems a very important and timely solution for the enhancement of energy security and minimization of negative environmental effect.

The studies are performed with the support of the Russian Science Foundation (Project No14-37-00050).

\section{References}

1. Data of Rosstat, Technological development of industries economy, Energy efficiency, URL: http://www.gks.ru/wps/wcm/connect/rosstat_main/rossta t/en/statistics/economydevelopment/ (circulation date 12.02.2018).

2. Energy in Australian mining sector. SunSHIFT Pty Ltd, 20 (2017)

3. D.R. Kaplunov, M.V. Ryl'nikova, D.N. Radchenko, J. Min. Sci, 51, 1, 111-117 (2015), DOI: 10.1134/S1062739115010147

4. Dr. Thomas Hillig Energy Consulting - THEnergy. Business Models for renewable energy applications at mines [Electronic resource]. URL: https://www.thenergy.net/english/platform-renewable-energy-andmining / business-models / (circulation date 03/03/2018). 5. S.M. Senderov, V.I. Rabchuk, N.I. Pyatkova, S.V. Vorobyov, Ensuring Russia's energy security: choice priorities. Sib. Otd-Institute of Energy Systems. L.A. Melentieva. Novosibirsk: Science, 116 (2017)

6. Pyatkova N.I. [and etc.]. Energy Security Russia: problems and solutions. Russian Acad. Sci., Sib. Branch, Institute of Systems power them. L.A. Melentieva., 146 (2014)

7. M.V. Rylnikova, K.I. Strukov, V.V. Olizarenko etc, Gornyi Zhurnal, 12, 71-76 (2017), DOI:10.17580/gzh.2017.11.13

8. VNTP 13-2-93. Norms of technological design mining enterprises of metallurgy with underground method of development, by the Committee of the Russian Federation on metallurgy (1993)

9. Rylnikova M.V., Radchenko D.N., Gadzhieva L.A., Materials Jubilee scientific and practical conference dedicated to the 100-anniversary of the RSGRUU. S. Ordzhonikidze "New in geological study of mineral resources ", 111-113 (2018) 